\title{
EMPIRICAL STUDY ON THE IMPLICATIONS OF QUALITATIVE FACTORS IN MAKING DECISIONS RELATED TO THE MATERIALITY LEVEL: THE CASE OF ROMANIA
}

\author{
Irimie Emil Popa ${ }^{a}$, Georgeta Span', Madalina Dumitruc, Valentin Florentin Dumitrud, Crina Loana \\ Filip \\ aBabes-Bolyai University, Faculty of Economics and Business Administration, Cluj Napoca, Romania, \\ irimie.popa@econ. ubbcluj.ro \\ ${ }^{b}$ Corresponding author: Babes-Bolyai University, Faculty of Economics and Business, Cluj Napoca, Romania, georgeta. \\ span@econ.ubbcluj.ro \\ cBucharest University of Ecomonic Studies, Bucharest, Romania, madalina.dumitru@cig.ase.ro \\ dBucharest University of Ecomonic Studies, Bucharest, Romania, valentin.dumitru@Soft-Expert.info \\ 'Babes-Bolyai University, Faculty of Economics and Business Administration, Cluj Napoca, Romania, crina.filip@econ. \\ ubbcluj.ro
}

\section{ARTICLE INFO}

Article data:

- Received: 06 October 2013

- Accepted: 18 November 2013

JEL classification: C38, C45, F32, N5

Keywords:

- Materiality level

- auditing

- qualitative factors

- quantitative benchmarks

\section{ABSTRACT}

The paper aims to present the importance of qualitative factors in determining the materiality level in an audit mission. According to the literature a quantitative approach of materiality is insufficient for appropriate decisions, therefore it is required a more serious treatment of this issue. Data collected in the research were processed using the Ordered Logit Model, and the results showed that there is a significant correlation between the materiality level and the sectors in which the audited companies operate, the auditor's experience in the field and the longevity of the relationship with the client. There is no any correlation between the materiality level and the needs of the users of financial statements or the management objectives. materiality level: The case of Romania, Ekonomska istraživanja - Economic Research 26(4): 43-58 


\section{INTRODUCTION}

The issue of the materiality in auditing has aroused much debate and divergence both in the literature (Krogstad et al., 1984; Libby and Kinney, 2000; Ng and Tan, 2007, etc.), and among professional bodies in the field (SEC, 1999; IFAC, 2006; AICPA, 2007). The intricacies of the method used to determine an adequate level of the materiality were and continue to be an essential objective of accounting and auditing professionals, even the more so as one of the causes of financial scandals (Waste Management, Sunbeam, Enron) which have ultimately led to the exclusion of Arthur Anderson auditing company from the "Big 5" category was considered to be the acceptance of some quantitatively insignificant transactions of such a nature that they endangered the financial stability of the entities, as well as the continuity of their activity.

In the professional field, the main method used to determine materiality consists in choosing a certain benchmark and applying a certain percentage to it. However, this procedure was severely criticised (Lewitt, 1998), considering that without adopting a dual quantitative-qualitative approach it is impossible to reach a real value against which a certain distortion can be considered significant. Professional auditing standards do not offer clear information, indication or solutions regarding materiality, stating that the decision depends on the auditor's professional judgment. (ISA 320)

The difficulty in establishing materiality resides in the qualitative aspects which can influence the materiality level. In order to apply the quantitative method, the first decision that requires the auditor's professional judgment is the choice of the benchmark which should be the basis in calculating the materiality (Turnover, Total assets, Gross profit, Net profit, Gross margin on sales, etc. or further indicators applied in various percentages). The second decision regards the percentage to be applied to the chosen benchmark, namely to the indicator which the auditor considers the most relevant to the audited entity. The difficulty arises in the qualitative aspects that should correct the mathematically calculated quantitative value. Auditor's opinion is especially important to all users of financial statements, particularly in decision making process, since it provides a higher level of assurance in information presented in company's financial statements (Stanisic et al., 2013). Given the importance of the opinion obtained in the auditing process for different stakeholders, the recent years witnessed the appearance of the audit in other fields (e.g. consumer protection, Surcel and Dinu, 2007; corporate social responsibility, Dragomir and Anghel (Ilcu), 2011; Albu et al., 2011).

\section{LITERATURE REVIEW}

The first studies in the field of materiality appeared in the '50s (Woosley, 1954 a,b); the essence of the auditor's decision was the application of a certain percentage to the indicator which was thought to be the most relevant. Research focused on the effect of financial factors on the materiality level. This approach was accepted until the early ' $80 \mathrm{~s}$. As a consequence of academic overview and empirical study, Holstrum and Messier (1982) showed that, in general, the basis in calculating materiality is net profit, to which a percentage ranging between 5 and 10 should be applied. Most studies show that net profit is the most widely used benchmark (Messier et al., 2005); however, this benchmark should be chosen depending on the relevance that it has to the audited entity. Moriarity and Barron (1979), subsequent to research carried out in five big American audit companies, show that profit is one of the most widely used benchmarks when calculating materiality, followed by total assets.

Pany and Wheeler (1989) considered five benchmarks that auditors generally use, the first four 
taken from Leslie (1985). The benchmarks are: $5 \%$ of net profit; $0.5 \%$ of total income; $0.5 \%$ of total assets; $1 \%$ of equity. The fifth benchmark refers to any of the aforementioned elements which has lately decreased, the materiality being determined proportionally to the decrease. According to Chewning and Higgs (2002), such benchmarks as total assets or total income are more stable over time (from one year to the next) than profit. Their study proposes the application of $0.5-1 \%$ to total assets or 1-2\% to income. Sweeney (1981) considers total income as the most important indicator, while Emery et al. (1981) and Gleason and Mills (2002) advocate the use of total assets as the main benchmark. Choosing a unanimously accepted benchmark appears to be extremely difficult. The relevance of each indicator seems to vary depending on the sector of activity in which the entity specialises Pany and Wheeler (1989).

Since 1980, the quantitative approach to materiality has been complemented with studies focusing on the implications of qualitative factors in substantiating such decisions. In a recent study, Libby and Kinney (2000) state that there are situations when errors that are quantitatively insignificant can be important from the viewpoint of the qualitative factors that characterise them and, consequently, the truthfulness of the picture given by the financial statement can be compromised. $\mathrm{Ng}$ and $\operatorname{Tan}$ (2007) consider that the strictly quantitative approach to materiality can lead to situations when reported financial data are misinterpreted, while qualitatively significant errors can be overlooked. Messier (1983) carried out a study on seven out of the eight audit companies belonging to the "Big 8 " group, one national and one regional company. The results indicate that decisions regarding the materiality are affected by the auditor's experience and by the type of audit company that the auditor belongs to. Experience as a qualitative factor determining the materiality level was also analysed by Krogstad et al. (1987), Arnold et al. (2001), Abdolmohammadi and Wright (1987), Bonner and Lewis (1990), Cohen and Hanno (2000), Pflugrath et al. (2007). Their studies show that auditors with more practical experience tend to apply higher materiality levels, whereas junior auditors (with less experience), for fear of errors, apply lower values.

The influence of the sector of activity on materiality was studied empirically by Iselin and Iskandar (2000). They state that auditors whose clients predominantly belong to the financial sector use lower materiality levels compared with auditors offering their services to entities in the commercial sector, who tend to adopt a more conservative approach for companies belonging to a sector with a higher market risk. Similar results were obtained by Sanchez (2001), according to whom auditors use lower materiality levels for financial entities quoted on the stock market. By contrast, higher materiality levels will be applied to industrial and operating companies to ensure a high degree of confidence in the accuracy of the financial statements. Nevertheless, Chewning et al. (1989), differentiating between services and production entities, found that sector of activity is not a significant factor that can contribute to justifying distortions in audit reports.

Academic literature mentions experience among the main qualitative factors that can contribute to the substantiation of professional judgment, decision regarding materiality included (Holstrum, 1982, Iskandar, 1999, Messier, 2005, etc). In our opinion, analysing the auditor's experience in a certain field, more precisely the auditor's expertise in a certain sector of activity, is much more relevant than testing the influence of practical experience on the auditor's decisions. Some empirical results point to the difference between the auditor's experience in a certain domain and his/her practical experience. The expertise of auditors is highly valued and auditing is considered as vital in imposing discipline upon management presentation of financial information (Stanisic et al., 2013). Because of the particular characteristics of the sector and, implicitly, of each individual entity, the materiality level will be adapted so as to ensure the most accurate representation in financial statements. 
Determining materiality by an auditor is something that depends on professional judgment and is affected by the auditor's perception of the needs of the users of the financial statements for financial information (ISA 320:4). When determining the materiality level, the auditor must know what the objective of the audit is and who the beneficiaries of the audit report are. Consequently, given the intricacy of the issue, other punctual aspects need to be considered, as found in some academic studies:

- Influence of information regarding the aim of using the audited financial statements and the nature of the audit engagement (Steinbart, 1987)

- Information about the main users of the financial statements (Krogstad et al., 1981)

- Objectives and tendencies of the management of the client entities (Wong-on-Wing, 1989, Carpenter and Dirsmith, 1992)

- Management integrity and competence (Chow et al., 2006)

- Impact of the client's financial position in devising corrections to detected distortions (Braun, 2001)

- Impact of the auditor's period of engagement in substantiating his/her decisions (Lin and Fraser, 2008).

In the audit practice, in addition to economic theory, there are national professional guidelines. In Romania, auditors apply the technical norms stipulated by the Guide to Quality Audit. GAQ mentions the following benchmarks to determine the materiality level: Total assets (before deducting debts) $1-2 \%$; Turnover $1-2 \%$ and Pre-tax profit $5-10 \%$. Choosing one of these indicators is a matter of professional judgment, but the choice needs to be adequately substantiated. In the present paper we carry out a study, on a national scale, in which we attempt to highlight the implication of certain factors in substantiating the professional judgment of Romanian auditors with regard to making decisions pertaining to the value of materiality. We analyse both the quantitative and the qualitative aspects and identify the benchmarks most frequently used by Romanian auditors, as well as the factors which influence the choice of a particular benchmark. The influence of certain qualitative factors on determining the materiality level is also tested econometrically.

\section{RESEARCH HYPOTHESES, DATA AND METHODOLOGY}

\section{A. RESEARCH HYPOTHESES}

Based on previous studies and on personal empirical observations we have constructed several working hypotheses.

H1: The choice of the benchmark to be considered in calculating the materiality differs depending on the sector of activity in which the audited entity specialises.

H2a: The materiality level (value) depends on the seniority (experience) of the auditor in the sector of activity to which the client entity belongs.

$\mathrm{H} 2 \mathrm{~b}$ : The materiality level differs depending on the sector of activity in question.

In order to formulate the third hypothesis, we identify a relation between the three basic elements: audited entity - auditor - users of the audited financial statements. By logical approach, the aim of an audit engagement is to obtain reasonable assurance with regard to the financial statements of an entity by an independent financial auditor in view of increasing the confidence 
of the users in the accuracy of the financial statements. Materiality can be influenced by factors associated with the audited entity or its management as well as by factors associated with external users. Consequently, the third hypothesis of our study focuses on testing the existence of a relation between the materiality level and the factors associated with the relationship management of client entity - auditor - external users.

H3: Professional judgment regarding the calculation of the materiality level is influenced by factors associated with entity management, auditor and users of the financial statements.

H3a: The materiality level (value) is influenced by the auditor's perception of the objectives and characteristics of the management of the client entity.

$H 3 b$ : The needs of the users of the audited financial statements influence the materiality level.

H3c: The longevity of the relationship with the audited client leads to a decrease in the materiality level.

\section{DATA}

Our study is based on an eight-item questionnaire referring to the factors associated with professional judgment regarding the materiality to be tested by the practical activity of auditors. The first part of the questionnaire includes general information referring to the auditors' expertise in a certain field, their experience, as well as the characteristics and the size of the audited entities. The second part of the questionnaire includes aspects regarding the choice of one of the three indicators given in GAQ and the factors which determine decision-making. Our study also aims to identify the qualitative factors which have the role of correcting the materiality level obtained by the quantitative method. The questionnaire was distributed to 270 active financial auditors, members of the Chamber of Financial Auditors of Romania in November 2011. Out of the 270 questionnaires distributed, 247 were validated as fully filled-in.

Each question was encoded as a variable. The correspondence between variables and questions is given in the Appendix, in the attached questionnaire.

FIN_BANK : dummy variable. Encoding for the finance-banking sector; it takes the value 1 if the answer indicates that the entity belongs to this field.

COMM_SERV : dummy variable. Encoding for the commerce and services sector.

INDUSTRY : dummy variable. Encoding for the industrial sector.

NGO : dummy variable. Encoding for non-governmental organisations.

EXPERIENCE_SECTOR: numerical variable - number of years that the auditor has operated in the sector of activity in which he/she specialises.

TURNOVER_LEVEL : numerical variable - average turnover of audited entities.

TOTAL_ASSETS : ordinal variable, scale from 1 to 10 . Importance of total assets as benchmark in determining materiality.

TURNOVER : ordinal variable, scale from 1 to 10 . Importance of turnover as benchmark.

EBIT : ordinal variable, scale from 1 to 10 . Importance of earnings before interest and taxes as benchmark.

MATERIALITY_LEVEL : ordinal variable, scale from 1 to 3. 
FIN_POS : ordinal variable, scale from 1 to 10 .

MNG_OBJ : ordinal variable, scale from 1 to 10.

CLIENT_REL : ordinal variable, scale from 1 to 10.

\section{METHODOLOGY}

The econometric analysis adopted in this study is limited to the Ordered Logit Model, a technique most frequently used in cross-sectional studies of dependent variables that take on only a finite number of values possessing a natural ordering. The Ordered Logit Model, estimates the effects of independent variables on the log odds of having lower rather than higher scores on the dependent variable. In its general form the model can be written as:

$$
\begin{gathered}
\operatorname{Prob}\left(y_{i}=j \mid x, b, c\right)=F\left(c_{j+1}-x_{i} b\right)-F\left(c_{j}-x_{i} b\right) \\
\operatorname{Prob}\left(y_{i}=j \mid x, b, c\right)=\frac{\exp \left(c_{j+1}-x_{i} b\right)}{1+\exp \left(c_{j+1}-x_{i} b\right)}-\frac{\exp \left(c_{j}-x_{i} b\right)}{1+\exp \left(c_{j}-x_{i} b\right)}
\end{gathered}
$$

$i=\overline{1, N}$ index of each auditor

$y_{i}=1 \quad$ if the auditor assigns 1 to the endogenous variable

$y_{i}=10$ if the auditor assigns 10

$x_{i}$ the vector of the exogenous variables

$b$ the coefficients' vector

$c_{j}, j=\overline{1,9}$ cutoffs

$c_{1}=-\infty, c_{j} \leq c_{j+1}, c_{5}=+\infty$ conditions that ensure that the probability sum for each interval equals 1 .

The Ordered Logit models are not linear in the parameters. In consequence, they are estimated by using maximum likelihood techniques.

\section{RESULTS}

An empirical analysis of the sample shows that the auditors' average practical experience is 6 years. This experience is significant considering that the auditing profession is relatively new in Romania and that qualified middle-aged persons predominantly gain access to the profession. The respondent auditors' average experience in a certain sector of activity is 4.15 years. This shows that it is not possible to equate the auditors' experience in carrying out assurance engagements with their 
expertise in a certain sector, which means that expertise in a certain sector influences the auditors' decisions in a different way than experience. The entities audited by the respondents belong to four activity fields: finance-banking (10.5\%), commerce and services (48.2\%), industry (31.6\%), and NGOs (9.7\%). With regard to the size of the audited entities, the average revenue of the entities mentioned in the study was EUR 7.6 million, the maximum value exceeding EUR 50 million. However, this descriptive statistics cannot account for causal relations since the analysis has been performed by the Ordered Logit Model.

TABLE 1: RELATION BETWEEN BENCHMARK INDICATOR AND SECTOR OF ACTIVITY - ORDERED LOGIT MODEL (COEFFICIENTS AND P-VALUES)

\begin{tabular}{|c|c|c|c|c|}
\hline & \multicolumn{4}{|c|}{ Endogenous variable } \\
\hline & TOTAL_ASSETS & TOTAL_ASSETS & TURNOVER & EBIT \\
\hline FIN_BANK & $-0.957^{* *}(0.021)$ & $0.000 \quad$ (ref.) & $0.902^{* *}(0.035)$ & $0.017 \quad(0.965)$ \\
\hline COMM_SERV & $-0.472^{*}(0.069)$ & $0.485 \quad(0.216)$ & $0.072 \quad(0.787)$ & $0.070 \quad(0.789)$ \\
\hline INDUSTRY & $0.000 \quad$ (ref.) & $0.957^{* *}(0.147)$ & $0.000 \quad$ (ref.) & $0.000 \quad$ (ref.) \\
\hline NGO & $0.046 \quad(0.911)$ & $1.003^{* *}(0.050)$ & $0.013 \quad(0.974)$ & $1.146^{* * *}(0.006)$ \\
\hline
\end{tabular}

Source: own calculations using STATA 9.1 software.

***, **, *: significant at $1 \%, 5 \%$ and $10 \%$ level

The results show that the auditors who audit entities belonging to the industrial sector or NGOs are more prone to choose total assets as a benchmark to determine materiality. This choice can be accounted for by the fact that industry, in general, requires large production capacities, while investment materialised in fixed assets represents a privileged and absolutely necessary element for the overall activity of the entities operating in this field. Turnover is preferred as a benchmark in the finance and banking sector since this sector is more volatile and market expansion is the main objective of the entities in the field. Turnover shows the sales volume, expansion and market position. The only sector that shows a preference for total profit is that of the NGOs. Similarly to profit in the case of commercial entities, surplus in the case of NGOs is the measure of credibility for the financiers of the projects undertaken. Hypothesis $\mathrm{H} 1$ regarding the relation between the audited sector and the chosen benchmark is confirmed.

We also try to identify a relation between the auditor's decision regarding the level of materiality and a) the auditor's experience in a certain sector of activity; b) the sector of activity to which the audited entity belongs; c) the financial position of the client (FIN_POS); d) the objective of the management (MNG_OBJ); and e) longevity of the relationship with the audited client. 
TABLE 2: FACTORS THAT INFLUENCE THE SIGNIFICANCE THRESHOLD LEVEL - ORDERED LOGIT MODEL

\begin{tabular}{llc}
\hline \hline & \multicolumn{2}{c}{ Endogenous variable: MATERIALITY_LEVEL } \\
\hline \hline & coefficient & p-value \\
FIN_BANK & $-0.871^{*}$ & 0.054 \\
COMM_SERV & $0.777^{* * *}$ & 0.006 \\
INDUSTRY & 0.000 & $($ ref. $)$ \\
NGO & $0.987^{* *}$ & 0.023 \\
EXPERIENCE_SECTOR & $0.087^{* *}$ & 0.053 \\
FIN_POS & -0.011 & 0.879 \\
MNG_OBJ & 0.080 & 0.266 \\
CLIENT_REL & $0.128^{* *}$ & 0.033 \\
\hline \hline
\end{tabular}

Source: own calculations using STATA 9.1 software.

***, *** *: significant at $1 \%, 5 \%$ and $10 \%$ level

The results of the regression show that hypothesis $\mathrm{H} 2 \mathrm{a}$ is accepted; there is a positive correlation between the materiality level and experience in the sector of activity. Practice and applied research in the field show that the richer the auditor's experience in a certain sector of activity, the higher the materiality level that he/she operates with. In other words, the auditor's degree of confidence increases with his/her experience. An auditor's good knowledge of a certain sector of activity offers him/her the opportunity to act on the elements that he/she considers delicate, thus being able to use a high materiality level. Conversely, insufficient knowledge of a sector of activity determines the auditor to be professionally sceptical and use low materiality levels.

Hypothesis $\mathrm{H} 2 \mathrm{~b}$ is a control hypothesis to verify the consistency of auditors' responses. If the materiality level differs depending on the auditors' knowledge of the characteristics and risks of a certain sector of activity, the values of the materiality will also differ depending on the sector of activity. Using the industrial sector as a benchmark, estimations show that auditors tend to use a lower materiality for the industrial sector and a higher one for commerce and services and NGOs. Hypothesis $\mathrm{H} 2 b$ is also accepted.

Out of the $\mathrm{H} 3$ group of hypotheses only hypothesis $\mathrm{H} 3 \mathrm{a}$ is accepted, longevity of the relationship with the client correlating with the level of materiality. However, we cannot evidence such a relation with regard to the client's position or management objective.

\section{CONCLUSIONS}

Our application has identified the existence of a correlation between the sector of activity of the audited entity and the benchmark chosen to determine the materiality level. Total assets are preferred for industry and NGOs, turnover for finance and banking, and total profit for NGOs. The results of the econometric estimations are consistent with economic logic. The materiality level chosen by auditors, too, depends on the sector of activity, experience in the field and the relationship with the client. However, we know that causal relations are much more intricate but we have not been able to evidence other mechanisms so far. 
The results of the study can have significant implications for audit practitioners and for the national professional body (CAFR) which is very much interested in knowing the way in which its members apply professional standards when carrying out their missions. As an overall conclusion of the study, we can state that auditors consider, intuitively, qualitative factors besides the quantitative method when determining the materiality. Highlighting these factors will allow for the transition from intuition to reason, with a positive impact on the effectiveness of the auditing activity.

\section{REFERENCES}

Abdolmohammadi, M., and Wright, A. (1987), An Examination of the Effects of Experience and Task Complexity on Audit Judgments, The Accounting Review, 62(1): 1-13.

Albu, N., Albu, C.N., Girbina, M.M., and Sandu, M.I. (2011), The Implications of Corporate Social Responsibility of the Accounting Profession: The Case of Romania, Amfiteatru Economic, 13(29): 221-235.

Arnold, D.F. Sr., R.A. Bernardi, and P.E. Neidermeyer (1999), The Effect of Independence on Decisions concerning Additional Audit Work: A European perspective, A Joumal of Practice \& Theory, 18: 45-67.

Arnold, D. F., Sr., R. A. Bernardi, and P. E. Neidermeyer (2001), The association between European materiality estimates and client integrity, national culture, and litigation, International Journal of Accounting, 36: 459-483.

Bates, H. L., Ingram, R. W., and Reckers, P. M. J. (1982), Auditor-client affiliation: The impact on materiality, Journal of Accountancy, 153(4): 60-63.

Bernardi, R. A., and D. F. Arnold, Sr. (1994), The influence of client integrity and competence and auditor characteristics on materiality estimates. Irish Accounting Review, 1(1): 1-23.

Braun, K.Wilken (2001), The Disposition of Audit-Detected Misstatements: An Examination of Risk and Reward Factors and Aggregation Effects, Contemporary Accounting Research, 18(1):71-99.

Boatsman, J.R., and J.C. Robertson (1974), Policy-capturing on Selected Materiality Judgments, The Accounting Review, p. 342-352.

Bonner, S.E., and B.L. Lewis (1990), Determinants of Auditor Expertise, Journal of Accounting Research, 28: 1-20.

Bonner, S.E. (1991), Is experience necessary in cue measurement? The case of auditing tasks, Contemporary Accounting Research, 8: 253-269.

Bonner, S.E, R. Libby, and M.W. Nelson (1996), Using Decision Aids to Improve Auditors' Conditional Probability Judgments, The Accounting Review, 71(2): 221-240.

Carpenter, B. W., and M. W. Dirsmith (1992), Early debt extinguishment transactions and auditor materiality judgments: A bounded rationality perspective, Accounting, Organizations and Society, 17(8): 709-740.

Carpenter, B. W., M. W. Dirsmith and P. P. Gupta (1994), Materiality judgments and audit firm culture: Social behavioral and political perspectives, Accounting, Organizations and Society, 19(4): 355-380. 
Chewning, G., K. Pany, and S. Wheeler (1989), Auditor reporting decisions involving accounting principle changes: Some evidence on materiality thresholds, Journal of Accounting Research, 27(1):78-96.

Chewning, G., W. Wheeler, and K. Chan (1998), Evidence on auditor and investor materiality thresholds resulting from equity-for-debt swaps, Auditing: A Journal of Practice \& Theory, 17(1):39-53.

Chow, C.W., J.L. Ho, and P.L. Lan Mo (2006), Toward Understanding Chinese Auditors' Structuring of Audit Approaches, Client Acceptance Decisions, Risk Assessment, and Stringency of Imposed Reporting Standards, Journal of International Accounting Research, 5(1): 1-23.

Chung, J.O.Y., J.R. Cohen, and G.S. Monroe (2008), The Effect of Moods on Auditors' Inventory Valuation Decisions, Auditing: A Journal of Practice \& Theory, 27(2): 137-159.

Cohen, J.R., L.W. Pant, and D.J. Sharp (1995), An Exploratory Examination of International Differences in Auditors ethical Perceptions, Behavioral Research in Accounting, 7: 37-64.

Cohen, J.R., Trompeter G.M. (1998), An Examination of Factors Affecting Audit Practice Development, Contemporary Accounting Research, 15(4): 481-504.

Dragomir, V.-D., Anghel, E.R. (2011), Social Responsibility Practices Regarding Facilities Granted to Employee and Consumer Protection in Selected European Companies, Amfiteatru Economic, 13(29): 86-103.

Emery, D.R., R. Thakkar, and S. Moriarity (1982), A Comparative Study of Materiality Judgments of Financial Statement Users and Auditors, Proceedings, Decision Sciences Institut National Meeting, 1: 5-7.

Estes, R., and D. D. Reames (1988), Effects of personal characteristics on materiality decisions: A multivariate analysis, Accounting \& Business Research, 18(72): 291-296.

Friedberg, A. H., J. R. Strawser, and J. H. Cassidy (1989), Factors affecting materiality judgments: A comparison of "Big Eight" accounting firms' materiality views with the results of empirical research, Advances in Accounting, 7: 187-201.

Frishkoff, P.A. (1970), An Empirical Investigation of the Concept Materiality in Accounting, Empirical Research in Accounting: Selected Studies, Journal of Accounting Research, 8: 283-295.

Gleason, C. A., and L. F. Mills (2002), Materiality and contingent tax liability reporting, The Accounting Review, 77(2): 317-342.

Hell, R. E. and D. Wang (2009), Cultural impact on the audit planning phase: An empirical study in China and France, Master thesis, two-year.

Hofstedt, T.R. and G.D. Hughes (1977), An Experimental Study of the Judgement Element in Disclosure Decisions, The Accounting review, 62(1): 379-395

Holstrum, G.L., and W.F. Messier, Jr. (1982), A Review and Integration of Empirical Research on Materiality, Auditing: A Journal of Practice \& Theory, 2(1): 45-63.

International Federation of Accountants (IFAC) (2006a): Proposed International Standard on Auditing 320 (revised and redrafted): Materiality in planning and performing an audit, Disponibil pe: http://www.ifac.org. 
International Federation of Accountants (IFAC) (2006b): Proposed International Standard on Auditing 450 (redrafted): Evaluation of misstatements identified during the audit, Disponibil pe: http://www.ifac.org.

Iskandar, T.M, and E.R. Iselin (1996), Industry type: a factor in materiality judgements and risk assessments, Managerial Auditing Journal, 11(3): 4-10.

Iskandar, T.M., and E.R. Iselin (1999), A review of materiality research, Accounting Forum, 23(3): 209-239.

Janvrin, D.J., and C.G. Jeffrey (2007), An Investigation of Auditor Perceptions about Subsequent Events and Factors That Influence This Audit Task, Accounting Horizons, 21(3): 295-312

Jenkins, J.G., and C.M. Haynes (2003), The Persuasiveness of Client Preferences: An Investigation of the Impact of Preference Timing and Client Credibility, Auditing: A Journal of Practice \& Theory, 22(1): 143-153.

Krogstad, J. L., R. T. Ettenson, and J. Shanteau (1984), Context and experience in auditors' materiality judgments, Auditing: A Journal of Practice \& Theory, 4(1): 54-74.

Krogstad, J.L., R. Ettenson, and J. Shanteau (1981), Materiality Judgments: The Development of Auditor Expertise, Working paper, Creighton University.

Leslie, D.A., (1985), Materiality:the concepts and its application to auditing, Toronto, Canada, Canadian Institute of Chartered Accountants.

Levitt, A. (1998), The numbers game, Remarks by Securities and Exchange Commission Chairman Arthur Levitt at the New York University Center for Law and Business, New York.

Libby, R., and D.M. Frederick (1990), Experience and the Ability to Explain Audit Findings, Journal of Accounting Research, 28(2): 348-367.

Libby, R., and W. R. Kinney, Jr. (2000), Does mandated audit communication reduce opportunistic corrections to manage earnings to forecast?, The Accounting Review, 75(4): 383-404.

Libby, R., M.W. Nelson, and J.E.Hunton (2006), Recognition v. Disclosure, Auditor Tolerance for Misstatement, and the Reliability of Stock-Compensation and Lease Information, Journal of Accounting Research, 44(3): 533-557.

Lin, Kenny Z., A.M. Fraser, and D.J. Hatherly, (2000), An Experimental Study of Auditor Analytical Review Judgements, Journal of Business Finance \& Accounting, p. 821-857.

Lin, Kenny Z., Fraser, A.M., (2008) “Auditors' Ability to Resist Client Pressure and Culture: Perceptions in China and the United Kingdom",Journal of International Financial Management and Accounting, p. 161-183.

Messier, W.F., Jr. (1981), An Analysis of Expert Judgment in the Materiality/Disclosure Decision, SE Aids Proceedings, p. 117-119.

Messier, W. F., Jr. (1983), The effect of experience and firm type of materiality /disclosure judgments, Journal of Accounting Research, 21(2): 611-618.

Messier, W.F., Jr., N. M. Bennie, and A. Eilifsen (2005), A Review and Integration of Empirical Research on Materiality: Two Decades Later, Auditing: A Journal of Practice \& Theory, 24(2): 153-187. 
Montoya del Corte, J., F.J.Martinez G., and A. Fernandez-Laviada (2008), La Utilization Efectiva de los Factores Cualitivos de la Materialidad: un Analisis Empirirco Para los Auditores de Cuentas Ejercientes en Espana - The Effective Use of Qualitive Materiality Factors: An Empirical Analysis for the Practicing Auditors in Spain, RC-SAR, 11(1), pp. 99-124.

Moriariry, S. and F. Barron (1976), Modeling the Materiality Judgments of Audit Partners, Journal of Accounting Research, 14(2): 320-341.

Moriariry, S. and F. Barron (1979), A Judgment-Based Definicion of Materiality, Journal of Accounting Research, 17: 114-135.

Nelson, M.W., R. Libby, and S.E. Bonner (1998), Knowledge Structure and the Estimation of Conditional Probabilities in Audit Planning, The Accounting Review, 70(1):27-47.

Nelson, M.W, J.A. Elliott, and R.L. Tarpley (2002), Evidence from Auditors about Managers' and Auditors' Earnings Management Decisions, The Accounting Review, 77: 175-202.

Nelson, M. W., S. D. Smith, and Z-V. Palmrose (2005), The effect of quantitative materiality approach on auditors' adjustments decisions, The Accounting Review, 80(3): 897-920.

Ng, T. B-P., and H-T. Tan (2003), Effects of authoritative guidance availability and audit committee effectiveness on auditors' judgments in an auditor-client negotiation context, The Accounting Review, 78(3): 801-818.

Ng, T. B-P., and H-T. Tan (2007), Effects of Qualitative Factor Salience, Expressed Client Concern, and Qualitative Materiality Thresholds on Auditors' Audit Adjustment Decisions, Contemporary Accounting Research, 24(4): 1171-1192.

O'Donnell, E., and E.N. Johnson (2001), The Effects of Auditor Gender and Task Complexity on Information Processing Efficiency, International Journal of Auditing, 5(2): 91-105.

Pany, K., and S. Wheeler (1989), Auditing: A comparison of various materiality rules of thumb, CPAJournal, 59(6): 62-63.

Pattilo, J. W. and J. D. Siebel (1973), The Concept of Materiality, Financial Executive, pp. 28-30

Pattilo, J. W. (1976), The Concept of Materiality in Financial Reporting, Financial Executive Research Foundation.

Pflugrath, G., N. Martinov-Bennie, and L. Chen (2007), The impact of codes of ethics and experience on auditor judgments, Managerial Auditing Journal, 22(6): 566-589

Robinson, C., and L. Fertuck (1985), Materiality: An Empirical Study of Actual Auditor Decisions. Research Monograph Number 12. Vancouver, British Columbia: The Canadian Certified General Accountants' Research Foundation.

Securities and Exchange Commission (SEC) (1999), Staff Accounting Bulletin No. 99: Materiality, Available on: http://www.sec.gov.

Stanisic M., Stefanovic D., Arezina N., and Mizdrakovic V. (2013), Analysis of auditor's reports and bankruptcy risk in banking sector in the Republic of Serbia, Amfitreatru Economic, 15(34): 431-441.

Steinbart, P. J. (1987), The construction of a rule-based expert system as a method for studying materiality judgments, The Accounting Review, 62(1): 97-116. 
Surcel, T. and Dinu, V. (2007), E-commerce audit connected with the consumer protection, Amfiteatru Economic, 9(21): 115-120.

Sweeney, J. A. (1980), Setting Materiality Criteria - The User's Viewpoint. Working paper, Cornell University.

Wheeler, S., K. Pany, and E. Chewning (1993), Inter-firm differences in propensities to modify audit opinions for pre-SAS No. 58 accounting principle changes, Accounting Horizons, 7(3): 46-54.

Woolsey, S. M. (1954a), Development of Criteria to Guide the Accountant in Judging Materiality, Journal of Accountancy, 97(2): 167-173.

Woolsey, S. M. (1954b), Judging Materiality in Determining Requirements for Full Disclosure, Journal of Accountancy, 98(6): 745-750.

Woolsey, S. M. (1973), Approach to Solving the Materiality Problem, Journal of Accountancy, 136(3): 47-50.

Wong-On-Wing, B., J. H. Reneau, and S. G. West (1989), Auditors' perception of management: Determinants and consequences, Accounting, Organizations and Society, 14(5): 577-587.

Wright, A., and S. Wright (1997), An examination of factors affecting the decision to waive audit adjustments, Journal of Accounting, Auditing \& Finance, 12(1): 15-36. 


\section{APPENDIX}

\section{QUESTIONNAIRE ON THE FACTORS THAT INFLUENCE THE MATERIALITY LEVEL}

1) To what sector do most of the entities that you have audited belong? (variables: FIN_ BANK,COMM_SERV, INDUSTRY, NGO):

finance-banking
services and commerce
industry
NGOs

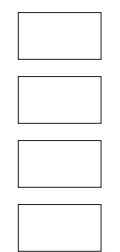

2) How long have you been auditing entities predominantly belonging to the sector of activity mentioned under question 1? (variable: EXPERIENCE_SECTOR)

Number of years

3) In your activity, the average turnover (variable: TURNOVER_LEVEL) of the entities belonging to the sector of activity chosen under question 1 falls in category:

Turnover:

$$
\begin{aligned}
& \text { Euro } 500.001-2.500 .000 \\
& \text { Euro } 2.500 .001-5.000 .000 \\
& \text { Euro } 5.000 .001-7.500 .000 \\
& \text { Euro } 7.500 .001-10.000 .000 \\
& \text { Euro } 10.000 .001-20.000 .000 \\
& \text { Euro } 20.000 .001-50.000 .000 \\
& \text { Euro } 50.000 .000+
\end{aligned}
$$

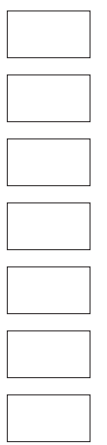

4) For the sector of activity chosen under question 1, please specify, according to your practical experience, an importance level (1 - unimportant; 10 - very important) for each of the following benchmarks (variables: TOTAL_ASSETS, TURNOVER, EBIT) that can be used to determine the materiality:

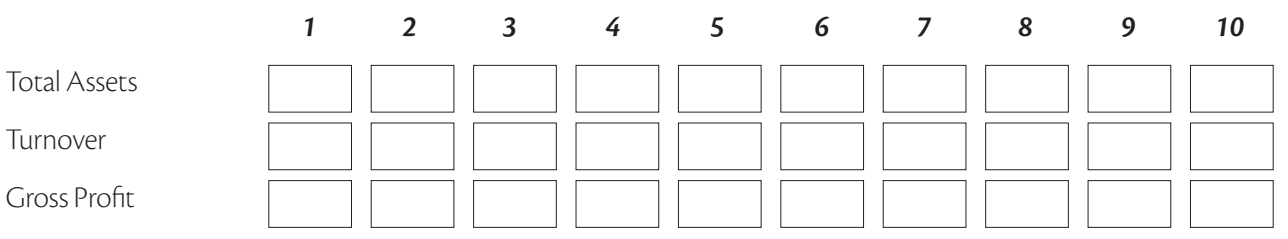

5) Indicate the materiality level that you applied in your latest auditing mission in one of your client entities belonging to the sector of activity chosen under question 1 (variable: MATERIALITY_LEVEL):

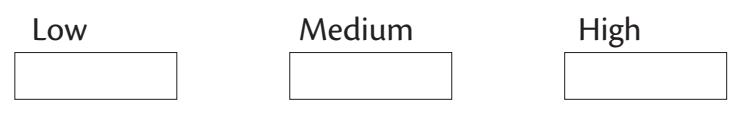


6) What importance level do you assign to the following factors (variables: FIN_POS, MNG_OBJ, CLIENT_REL) in determining the materiality level (1-insignificant, 10-very important)?

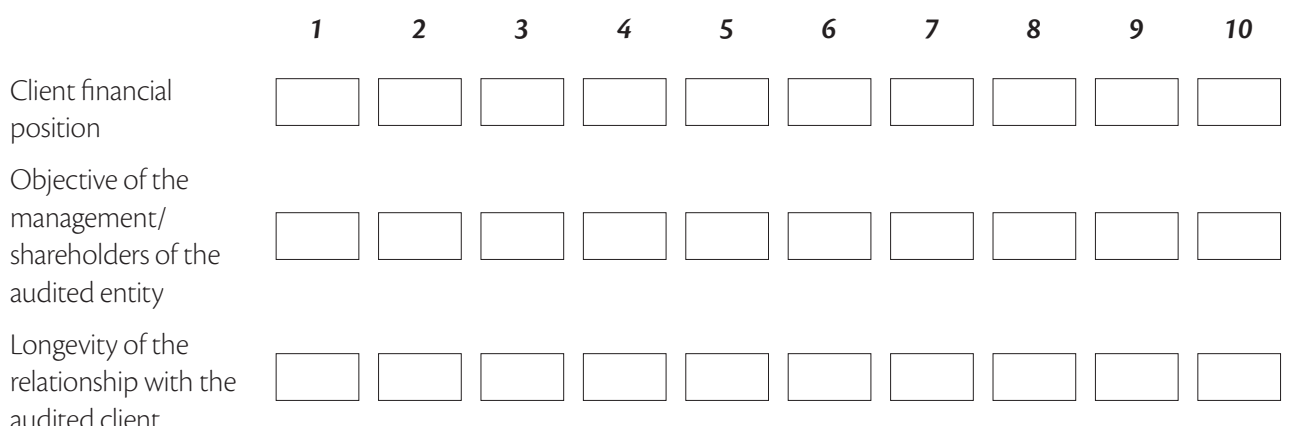
audited client 


\title{
EMPIRIJSKA STUDIJA IMPLIKACIJA KVALITATIVNIH FAKTORA U DONOŠENJU ODLUKA VEZANIH ZA RAZINU MATERIJALNOSTI. SLUČAJ RUMUNJSKE
}

\begin{abstract}
Sažetak
Rad želi predstaviti važnost kvalitativnih faktora u određivanju razine materijalnosti u postupku revizije. Literatura nam govori da kvantitativni pristup materijalnosti nije dovoljan za prikladne odluke, te je stoga potreban ozbiljniji pristup ovoj temi. Podaci sakupljeni u istraživanju obrađeni su pomoću Order Logit Modela a rezultati su pokazali da postoji značajna korelacija između razine materijalnosti i sektora u kojima djeluju revidirane tvrtke, revizorovo iskustvo na polju dugovječnosti odnosa s klijentom. Ne postoji nikakva korelacija između razine materijalnosti i potreba korisnika financijskih izvještaja ili ciljeva menadžmenta.
\end{abstract}

Ključne riječi: razina materijalnosti, revizija, kvalitativni faktori, kvantitativna mjerila 